\title{
Eco-Friendly Measures for Control of Phomopsis vexans and Other Mycoflora of Brinjal
}

\author{
Y.N. Priya Reddy ${ }^{*}$, S.S. Jakhar and O.S. Dahiya \\ Department of Seed Science and Technology, College of Agriculture, CCS HAU, \\ Hisar-125004, Haryana, India \\ *Corresponding author
}

\section{A B S T R A C T}

\section{Keywords}

Mycoflora, Plant oils, Bio-fungicides, Carbendazim

Article Info

Accepted:

26 April 2018

Available Online:

10 May 2018
The brinjal variety Hisar Shyamal (H-8) is popular among farmers in the state of Haryana and neighbouring states of India. It experiences huge losses in fruit yield as it is not resistant to devastating seed borne diseases viz. damping off and fruit rot caused by Phomopsis vexans in addition to other mycoflora. Seed treatment with chemical fungicides like carbendazim is a common practice to control these seed borne diseases of brinjal. However, continuous use of these chemical fungicides are not safe both environmentally and human health point of view. Therefore, we have evaluated different plant oils and biofungicides as seed treatment for control of Phomopsis vexans and other mycoflora as an alternative eco-friendly measure. The results revealed that the healthy seed not only affected by $P$. vexans but also by other mycoflora viz. Aspergillus, Alternaria, Penicillium and Cercospora. Seed treated with neem oil $\left(5 \mathrm{ml} \mathrm{kg}^{-1}\right.$ seed) and Trichoderma viride $(10 \mathrm{~g}$ $\mathrm{kg}^{-1}$ seed) found effective in controlling the infection caused by P.vexans comparable to that of carbendazim with an improved shoot growth. Hence, seed treatment with neem oil (5 ml kg ${ }^{-1}$ seed) and Trichoderma viride (10 $\mathrm{g} \mathrm{kg}^{-1}$ seed) are effective alternatives to the chemical fungicide, carbendazim in view of safe environment.

\section{Introduction}

Brinjal is an important vegetable crop in India and occupies $0.727 \mathrm{~m}$.ha with a production of 12.3 m.t (NHB, 2017). One of the production constraints is fungal diseases like seedling blight and fruit rot caused by Phomopsis vexans in addition to several other seed born fungi (Udaykumar et al., 1981) leading to yield loss up to 50 per cent (Beura et al., 2008) and therefore, seed treatment is indeed essential. For control ofsuch, fungal diseases, many chemical fungicides in particular the carbendazim $(0.2 \%)$ are commonly used in brinjal (Habib et al., 2007; Phansawan et al., 2015). However, indiscriminate use in a long run lead to residual toxicity, induced resistance to pathogen, environmental pollution and side effects on human and animal health (Rajavel, 2000; Avinash and Hosmani, 2012). Hence, identification of plant-based compounds and or bio-fungicides would be better alternatives in the changing climate scenario. Therefore, two studies were conducted to evaluate the plant oils and biofungicides in comparison with carbendazim. 


\section{Materials and Methods}

Two experiments namely, effect of plant oils on seed mycoflora and; effect of biofungicides on seed mycoflora incidence of brinjal were conducted during 2016-17 at the Department of Seed Science and Technology, CCS HAU, Hisar, Haryana. The high yielding variety, Hisar Shyamal (H-8) was harvested during March-April 2016, stored for six months and used in the present experiments. Such seeds were surface sterilized for 2 minutes using $1.0 \quad \% \quad(\mathrm{v} / \mathrm{v})$ sodium hypochlorite, washed with sterilized distilled water thoroughly and then treated with different plant oils (castor, neem, aonla, sesamum, linseed, pongamia, walnut and ajwain) for one hour @ $5 \mathrm{ml} \mathrm{kg}^{-1}$ seed and shade dried overnight. In the second experiment, the seeds were dressed with biofungicides (Trichoderma viridae, Trichoderma asperellum and Pseudomonas fluorescens) @ $10 \mathrm{~g} \mathrm{~kg}^{-1}$ seed as individually or in combination $(5+5 \mathrm{~g})$ of bio-fungicides for 10 minutes and used for the experiment. The checks for these experiments were carbendazim $(0.2 \% \quad \mathrm{w} / \mathrm{w})$ and untreated healthy seed.

The treated seeds were placed in petri dishes lined with two layers of filter paper (Whatman No.1) and incubated for seven days in BOD incubator at $25+1^{0} \mathrm{C}$. Each treatment had three replications and in each replication, 25 seeds were placed in petri-dish equidistantly. The petri-dishes were watered using sterilized distilled water as when required. After seven days of incubation, observations were made on different mycoflora around the seeds based on morphological features namely, colony colour and pattern of growth. The identification is as follows, (i) C. capsici white to light grey circular colony with fluffy mycelium, (ii) Alternaria - greenish white colour colony with dark brown hyphae, (iii) Aspergillus - black cottony mycelia, (iv)
Penicillium - green colony and (v) Cercospora - small, irregular shape, charcoal black colonies)and confirmed under microscope. Each species of mycoflora incidence was enumerated as (i) 0 (no mycoflora), (ii) + (1 to 3 numbers), (iii) ++ (3 to 7 numbers) and (iv) +++ (more than 8 numbers) in a plate of 25 seeds, which represents no mycoflora incidence, low incidence, moderate incidence and high incidence respectively.

\section{Results and Discussion}

Seed is a primary source of inoculum carrier for the plant disease from one generation to the next. Seed borne microorganisms play a vital role in affecting the seed germination, seed quality parameters and subsequent crop yield. In the present studies, brinjal seeds harvested and stored for six months found infected not only by the Phomopsis vexans but also other mycoflora like Cercospora sp., Penicillium sp., Aspergillum sp. and Alternaria sp. (Table 1 and 2). In this line, in blotter method, Udaykumar et al., (1981) have reported 32 species of fungi and among them; the prominent were Alternaria, Aspergillus, Cercospora, Penicillium and Phoma. These mycoflora produce toxins and thus inhibits seed germination leading to unhealthy stunted seedlings (Udaykumar et al., 1981). Therefore, control of these fungi is very essential to decrease the disease incidence to enhance the fruit yield.

Several chemical fungicides viz., thiram, captan, carbendazim etc. found effective in controlling the fungal pathogens including Colletotrichum capsici and Phomopsis vexans by inhibiting the mycelia and colony growth (Mesta et al., 2007; Singh et al., 2012; Hossain et al., 2013; Bhoyar et al., 2014). However, the continuous or indiscriminate use lead to residual toxicity, induced resistance to pathogen, environmental pollution and side effects on human and animal health (Rajavel, 
2000; Avinash and Hosmani, 2012) and hence, it would be more pertinent to use bio-agents.

In the present study, the cumulative seed mycoflora across the plant oil treatments revealed that, the cumulative Aspergillum sp. incidence was moderate (17 No.) followed by Phomopsis vexans and Alternaria (low incidence, 10 No.) (Table 1). Similarly, Aidoo et al., (2011) reported that the Aspergillus is a predominant fungus $(21.5 \%)$ followed by Penicillium $(17.0 \%)$ and similar pattern of incidence was reported by Bhajbhuje (2013), Singh and Sharma (2013) and Ashiq et al., (2017). Such dominance by Aspergillus could be due to competitive inhibition of $P$. vexans, which could be due to suppression of germination and growth of C. capsici as reported in chilli (Gupta, 2016).
Among the plant oils, the neem oil found effective in controlling the cumulative mycoflora on par to that of carbendazim especially in inhibition of $P$. vexans and Cercospora sp. (Table 1). Whereas, healthy seed (un treated) has higher incidence by three times and hence treatment with fungicides is essential and; would be apt to use plant oils such a neem oil @ $5 \mathrm{~g} \mathrm{~kg}^{-1}$ seed to control the seed mycoflora particularly the Phomopsis vexans. Chethana et al., (2012) also observed that, the plant oils like neem and pongamia (@ $20 \%$ ) recorded 76.9 and 69.9 per cent inhibition of mycelia growth respectively. Bhardwaj et al., (2013) reported that the neem was most effective in reducing the Aspergillus in peas. In addition, neem oil is effective in controlling the shoot and fruit borer also (Yadav et al., 2015).

Table.1 Effect of plant oils on seed mycoflora incidence in brinjal seeds

\begin{tabular}{|c|c|c|c|c|c|c|}
\hline \multirow{2}{*}{$\begin{array}{c}\text { Seed } \\
\text { treatment }\end{array}$} & \multicolumn{6}{|c|}{ Mycoflora incidence } \\
\hline & $\begin{array}{l}\text { Phomopsis } \\
\text { vexans }\end{array}$ & $\begin{array}{c}\text { Cercospora } \\
\text { sp. }\end{array}$ & $\begin{array}{c}\text { Alternaria } \\
s p .\end{array}$ & $\begin{array}{c}\text { Penicillium } \\
\text { sp. }\end{array}$ & $\begin{array}{c}\text { Aspergillus } \\
\text { sp. }\end{array}$ & $\begin{array}{c}\text { Cumulative } \\
\text { incidence }\end{array}$ \\
\hline Castor & ++ & + & + & + & ++ & 7 \\
\hline Neem & 0 & 0 & + & + & + & 3 \\
\hline Aonla & + & + & + & + & ++ & 6 \\
\hline Sesame & + & + & 0 & 0 & ++ & 4 \\
\hline Linseed & + & + & + & + & + & 5 \\
\hline Pongamia & + & + & + & 0 & ++ & 5 \\
\hline Walnut & + & + & ++ & 0 & + & 5 \\
\hline Ajwain & + & + & 0 & + & ++ & 5 \\
\hline Healthy seed & ++ & + & ++ & + & +++ & 9 \\
\hline Carbendazim & 0 & 0 & + & + & + & 3 \\
\hline $\begin{array}{l}\text { Cumulative } \\
\text { incidence }\end{array}$ & 10 & 7 & 10 & 8 & 17 & 52 \\
\hline
\end{tabular}

Note:

0 : No disease incidence

+ : Low disease incidence

++ : Moderate disease incidence

+++ : High incidence disease 
Table.2 Effect of bio-fungicides on seed mycoflora incidence in brinjal seeds

\begin{tabular}{|l|}
\hline Treatments \\
\hline Trichoderma viride \\
\hline Trichoderma asperellum \\
\hline Pseudomonas fluorescens \\
\hline Trichoderma viride + \\
Trichoderma asperellum \\
\hline Trichoderma viride + \\
Pseudomonas fluorescens \\
\hline Trichoderma asperellum \\
+ Pseudomonas \\
fluorescens \\
\hline Healthy seed \\
\hline Carbendarim \\
\hline Cumulative incidence \\
\hline
\end{tabular}

\begin{tabular}{|c|c|c|c|c|c|}
\hline $\begin{array}{c}\text { Phomopsis } \\
\text { vexans }\end{array}$ & $\begin{array}{c}\text { Cercosporas } \\
\mathrm{p}\end{array}$ & $\begin{array}{c}\text { Alternaria } \\
\mathrm{sp}\end{array}$ & $\begin{array}{c}\text { Penicillium } \\
\mathrm{sp}\end{array}$ & $\begin{array}{c}\text { Aspergillus } \\
\mathrm{sp}\end{array}$ & $\begin{array}{c}\text { Cumulative } \\
\text { incidence }\end{array}$ \\
\hline 0 & 0 & + & + & 0 & $\mathbf{2}$ \\
\hline+ & + & 0 & 0 & ++ & $\mathbf{4}$ \\
\hline+ & + & + & ++ & 0 & $\mathbf{5}$ \\
\hline 0 & + & 0 & + & ++ & 4 \\
\hline 0 & + & + & + & 0 & $\mathbf{3}$ \\
\hline+ & + & 0 & + & & \\
\hline & & & & + & $\mathbf{4}$ \\
\hline++ & + & ++ & + & +++ & $\mathbf{9}$ \\
\hline 0 & 0 & + & + & + & $\mathbf{3}$ \\
\hline
\end{tabular}

Note:

0 : No disease incidence

$+:$ Low disease incidence

++ : Moderate disease incidence

+++ : High incidence disease

Plate.1 Comparison of seedling health and seedling growth of brinjal among, Seed infected with Phomopsis vexans, (b) Healthy uninfected seed, (c) Infected seed treated with carbendazim and (d) Infected seed with neem oil

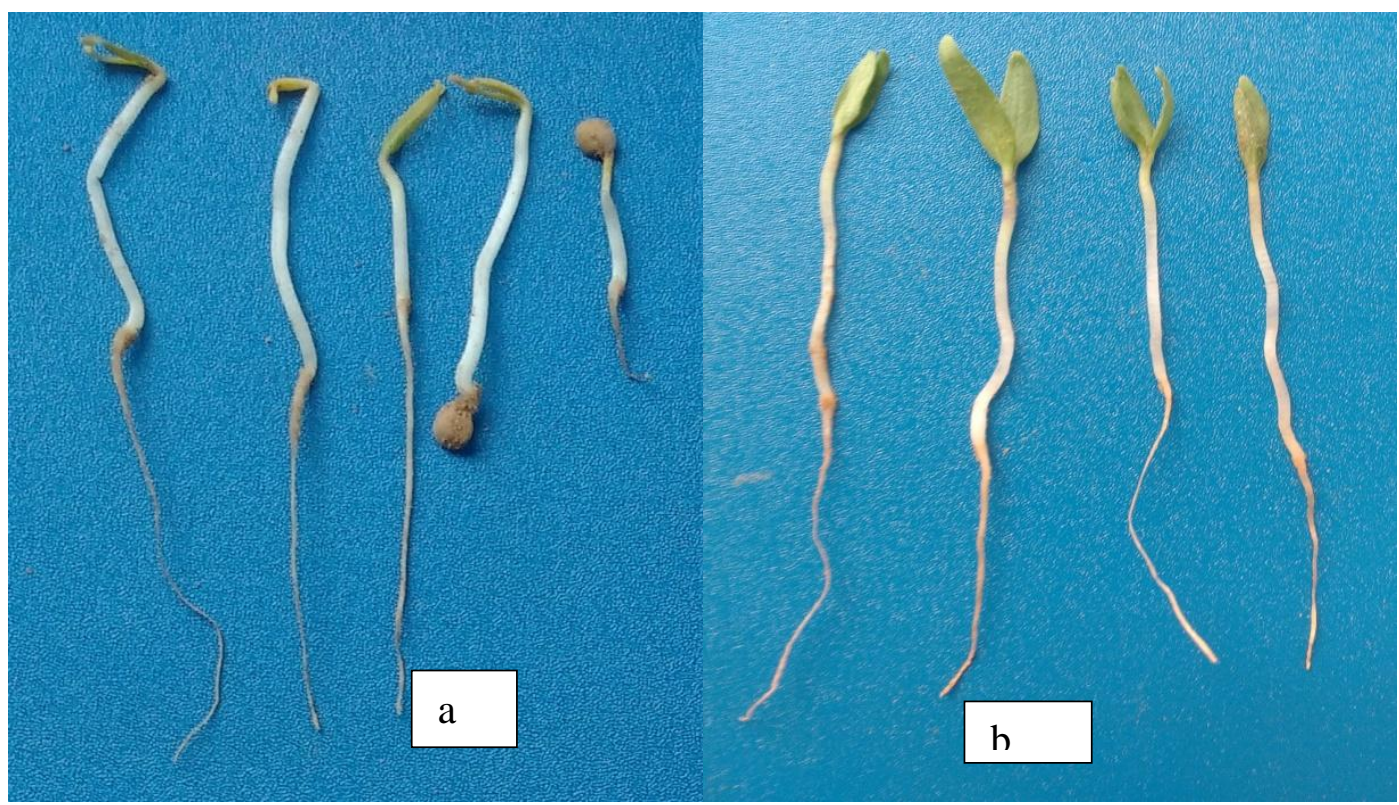




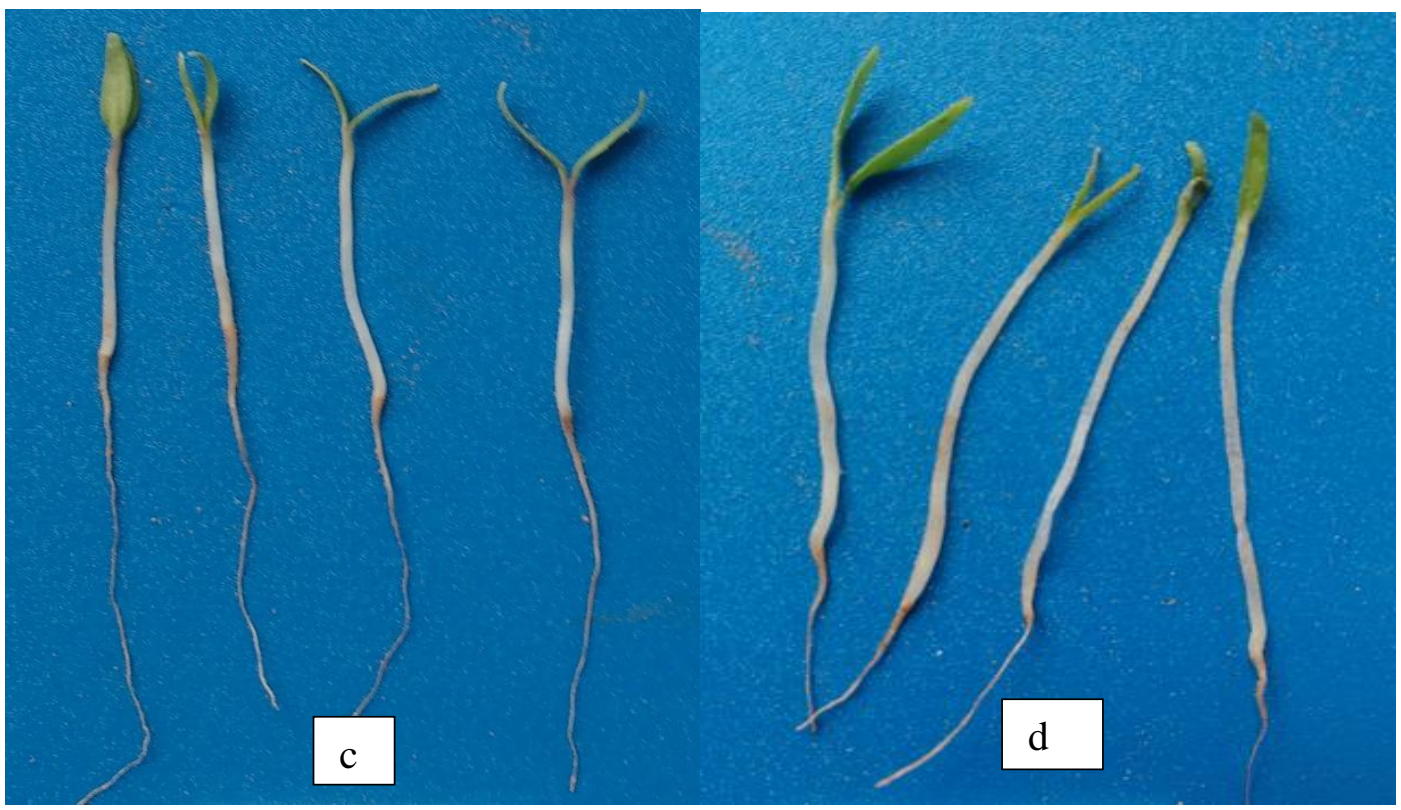

The other approach for use of bio-agents to control the mycoflora could be the use of biofungicides. The cumulative mycoflora across different bio-fungicides was highest by Aspergillus sp. (9 No.) followed by Penicillium (8 No.) and with a least by $P$. vexans (5 No.) (Table 2).Such a lower infestation by $P$. vexans could be due to competitive inhibition by Aspergillus (Gupta, 2016). Among the bio-fungicides, cumulative incidence of mycoflora was least with Trichoderma viridae treatment (2 No.) as against carbendazim (3 No.) and untreated seed (9 No.) (Table 2). Similar to our results, Bhoyar et al., (2014) reported $100 \%$ control of mycoflora by chemical fungicide followed by followed by $T$. harzanium $(75 \%)$ in case of cowpea. Further, Mogle and Maske (2012) reported an improvement in efficiency of biofungicide through addition of plant extracts, wherein, Trichoderma viridae along with plant extracts found to decrease the incidence of Aspergillus, Penicillium by $93 \%$ and $75 \%$ respectively, compared to the control. These treatments were on par to the bavistin with additional benefit of increase in seed germination, root length, shoot length and seedling vigour index. In the present study, the Trichoderma viridae found effective in controlling the mycoflora especially the $P$. vexans (Table 2) and therefore, the biofungicides can be effectively used to control seed mycoflora of brinjal seed.

The cumulative incidence of mycoflora across plant oils as well as bio-fungicides showed that the cumulative mycoflora incidence was 52 No. and 34 No. respectively (Table 1 and Table 2). Among plant oils, the neem oil showed least mycoflora incidence especially the $P$. vexans. Among the bio-fungicides Trichoderma viridae and its combinations was able to achieve 100 per cent control of $P$. vexans. These results suggest that the Phomopsis seedling blight and fruit rot can be effectively controlled by seed treatment with neem oil comparable to that of carbendazim $(0.2 \%)$ treatment. Further, the data show that the seed treatment with neem oil found effective in maintaining normal healthy seedling and comparable to that of carbendazim (Plate 1). The seedling health is in these two treatments were similar to healthy seedlings and superior to infected seed with $P$. vexans (Plate 1). Interestingly the shoot length was higher in neem oil treatment and vice-versa with the carbendazim treatment (Plate 1). 
The experimental results in overall infer that, the neem oil ( $5 \mathrm{ml} \mathrm{kg}^{-1}$ seed) or Trichoderma viridae (10 $\mathrm{g} \mathrm{kg}^{-1}$ seed) would be effective in controlling the seed borne mycoflora as comparable to that of carbendazim $(0.2 \%)$, a chemical fungicide.

\section{Acknowledgements}

I am thankful to Dr. R.C. Punia, Dr. S.S. Verma, Dr. V.S. Mor, Dr. Axay Bhuker and Dr. V.P.S. Sangwan, Department of Seed Science \& Technology, CCSHAU, Hisar for their kind support in conducting the experiment and; Dr. M.K. Prasanna Kumar and Dr. Y.A. Nanja Reddy, UAS, Bangalore for their suggestions in preparation of this manuscript.

\section{References}

Aidoo, A.K., Appiah-Kubi, Z. and Kwodane, M. 2011. Contamination of stored seed of four eggplant cultivars by mycoflora. Journal of Basic and Applied Research International.17: 172-175.

Ashiq, B., Chohan, S., Parveen, R., Abid, M. and Mohammad, M.A. 2017. Chemical composition and antifungal potential of medicinal plants against seed borne mycoflora of eggplant. ActaBotanica.Croatica.76 (1): 72-79.

Avinash, V. S. and Hosmani, S. P. 2012. Effect of carbendazim on morphological and biochemical parameters of Sorghum bicolor. Indian Journal of Research. 1(10): 12-14.

Beura, S.K., Mahanta, I.C. and Mohapatra, K.B. 2008. Economics and chemical control of Phomopsis twig blight and fruit rot of brinjal. Journal of Mycopathological Research. 46 (1): 7376.

Bhajbhuje, M.N. 2013.Biodiversity of mycoflora in storage of Solanum melongena L. seeds. International Journal of Life Sciences. 1(3): 165-181.

Bhardwaj, A., Verma, S., Bharat, N. K. and Thakur, M. 2013.Effect of vegetable oil seed treatment on seed mycoflora of pea (Pisum sativum L). International Journal of Farm Science. 3(2): 46-51.

Bhoyar, P.R., Chandankar, V. D., Bagde, V. L., Borkar, D. B. and Sonone, J.S. 2014. Studies on seed borne mycoflora and effect of bio-agents and fungicides on wheat seed health. The Bioscan. 9(3): 1285-1289.

Chethana, B. S., Ganeshan, G., Rao, A. S. and Bellishree, K. 2012. In vitro evaluation of plant extracts, bio-agents and fungicides against Alternaria porri (Ellis) Cif, causing purple blotch disease of onion. Pest Management in Horticultural Ecosystems. 18(2): 194198.

Gupta, V. 2016. Studies on Anthracnose disease of chilli (Capsicum annuum L.) caused by Colletotrichum capsici (Sydow) Butler and Bisby. M.Sc. (Agri) thesis, Department of Plant Pathology, Rajmata Vijayaraje Scindia Krishi Vishwa Vidyalaya, Gwalior (M.P.)

Habib, A., Sahi, S.T., Ghazanfer, M.U. and Ali, S. 2007. Evaluation of some fungicides against seed born mycoflora of eggplant and their comparative efficacy regarding seed germination. International Journal of Agriculture and Biology. 9 (3): 519-520.

Hossain, M.I., Islam, M.R., Uddin, M.N., Arifuzzaman, S.M. and Hasan, G.N. 2013. Control of Phomopsis blight of eggplant through fertilizer and fungicide management. International Journal of Agricultural Research, Innovation and Technology. 3(1): 66-72.

Mesta, R.K., Kulkarni, V.R. and Rao, M.S.L. 2007. Studies on seed borne nature of C. capsici causing seedling blight and its control through chemicals. 
International Journal of Agricultural Sciences. 3 (1): 35-38.

Mogle, P.U. and Maske, S.R. 2012. Efficacy of bio-agents and fungicides on seed mycoflora, germination and vigour index of cowpea. Science Research Reporter. 2: 321-326.

NHB. 2016. Area and production of horticultural crops - All India, www.nhb.gov.in, areapro_15-16, Pp.34.

Phansawan, B., Prapamontol, T. Thavornyutikarn, P., Chantara, S., Mangklabruks, A. and Santasup, C. 2015. A sensitive method for determination of carbendazim residue in vegetable samples using HPLC-UV and its application in health risk assessment. Chiang Mai Journal of Science. (3): 681-690.

Rajavel, R. 2000. Seed borne Colletrotrichum capsici and its management. M.Sc. Thesis. Tamil Nadu Agricultural University, Coimbatore, India.
Singh, N. and Sharma, C. 2013. Antagonistic effect of bio-fertilizers against seed borne mycoflora of brinjal (Solanum melongena). Biotechnology Today. 3(1): 24-26.

Singh, R., Singh, P.C., Dinesh, K. and Sachin, N.S. 2012. Management of Phomopsis leaf blight of brinjal through different fungicides and bio-pesticides. HortFlora Research Spectrum. 1(4): 371-374.

Udaykumar, R., Safeeulla, K.M., Shetty, H.S. and Subramanya, S. 1981. Seed mycoflora of brinjal (Solanum melongena L.).Proceedings of Indian National Science Academy. B47 (4): $567-573$.

Yadav, R., Lyall, H., Kumar, S. and Rameshkumar, S. 2015. Efficacy of certain botanical insecticides against shoot and fruit borer, Leucinodes orbonalis (Guenee) on brinjal (Solanum melongena L.). The Bioscan. 10(2): 987-990.

\section{How to cite this article:}

Priya Reddy, Y.N., S.S. Jakhar and Dahiya, O.S. 2018. Eco-Friendly Measures for Control of Phomopsis vexans and Other Mycoflora of Brinjal. Int.J.Curr.Microbiol.App.Sci. 7(05): 36673673. doi: https://doi.org/10.20546/ijcmas.2018.705.423 